\title{
ANALISIS KESEDIAAN MEMBAYAR (WILLINGNESS TO PAY) BUAH-BUAHAN PADA RUMAH TANGGA DI KELURAHAN CIMUNING, KECAMATAN MUSTIKA JAYA, KOTA BEKASI SAAT PANDEMI COVID-19
}

\author{
ANALYSIS OF WILLINGNESS TO PAY FOR FRUITS IN HOUSEHOLDS \\ IN CIMUNING VILLAGE, MUSTIKA JAUA DISTRICT, BEKASI CITY \\ DURING THE COVID-19 PANDEMIC
}

\author{
Dhifa Prilia Purnomo*, Trisna Insan Noor, Eliana Wulandari, Lucyana Trimo \\ Program Studi Agribisnis, Fakultas Pertanian, Universitas Padjadjaran \\ Jl. Raya Jatinangor Sumedang Km. 21 \\ *Email: dhifa.prilia@gmail.com \\ (Diterima 10-08-2021; Disetujui 15-12-2021)
}

\begin{abstract}
ABSTRAK
Covid-19 merupakan satu wabah yang berasal dari Wuhan, China dan menyebar ke Indonesia. Penyebaran Covid-19 di Indonesia terjadi begitu cepat dan perkembangan kasus positif di Indonesia meningkat setiap hari sampai tahun 2021. Kementerian Kesehatan RI merekomendasikan beberapa buah untuk memenuhi asupan gizi selama pandemi Covid-19 yaitu semangka, apel, stroberi, anggur merah, pisang, jeruk, pepaya, mangga, nanas, apel malang, anggur hijau, melon, alpukat dan manggis. Salah satu daerah di Jawa Barat adalah RW 10 Kelurahan Cimuning, Kecamatan Mustika Jaya, Kota Bekasi. Daerah tersebut merupakan salah satu daerah yang beberapa warganya terjangkit Covid-19. Keadaan seperti ini, membuat rumah tangga pada daerah tersebut memiliki pertimbangan antara kesehatan yang harus selalu dijaga dengan pendapatan rumah tangga yang merupakan dampak dari pandemi Covid-19. Penelitian ini bertujuan untuk mendeskripsikan karakteristik rumah tangga yang membeli buah-buahan selama pandemi Covid19, Berapa nilai yang bersedia dibayarkan oleh rumah tangga untuk buah-buahan selama pandemi Covid-19 dan faktor-faktor apa saja yang memengaruhi nilai kesediaan membayar buah-buahan pada rumah tangga selama pandemi Covid-19. Penelitian ini menggunakan desain kuantitatif dan metode survei dengan menggunakan kuesioner. Analisis yang digunakan adalah uji instrumen, analisis statistik deskriptif, contingent valuation method, skala likert dan analisis regresi linier berganda. Hasil penelitian menunjukkan nilai rataan kesediaan membayar (Willingness To Pay) terhadap buah-buahan oleh rumah tangga di RW 10, Kel. Cimuning, Kec. Mustika Jaya, Kota Bekasi sangat bervariasi berbeda setiap jenis buahnya. Buah dengan nilai rataan WTP tertinggi adalah anggur hijau dengan nilai $\mathrm{Rp} 83.000 / \mathrm{kg}$, dan buah dengan nilai rataan WTP terendah adalah pepaya dengan nilai Rp 17.000/kg. Faktor-faktor yang memengaruhi kesediaan membayar buahbuahan pada rumah tangga selama pandemi Covid-19 adalah dampak kesehatan, jumlah anggota keluarga dan harga produk.
\end{abstract}

Kata Kunci: Kesediaan Membayar, CVM, Buah-Buahan, Kecamatan Mustika Jaya, Covid-19

\section{ABSTRACT}

Covid-19 is an outbreak that originated in Wuhan, China and spread to Indonesia. The spread of Covid-19 in Indonesia is happening so fast and the development of positive cases in Indonesia is increasing every day until 2021. The Indonesian Ministry of Health recommends several fruits to meet nutritional intake during the Covid-19 pandemic, namely watermelon, apples, strawberries, red grapes, bananas, oranges. , papaya, mango, pineapple, poor apple, green grapes, melon, avocado and mangosteen. One of the areas in West Java is RW 10 Cimuning Village, Mustika Jaya District, Bekasi City. The area is one of the areas where several residents have contracted Covid19. Circumstances like this have made households in these areas have considerations between 


\section{ANALISIS KESEDIAAN MEMBAYAR (WILLINGNESS TO PAY) BUAH-BUAHAN \\ PADA RUMAH TANGGA DI KELURAHAN CIMUNING, KECAMATAN MUSTIKA JAYA, \\ KOTA BEKASI SAAT PANDEMI COVID-19 \\ Dhifa Prilia Purnomo, Trisna Insan Noor, Eliana Wulandari, Lucyana Trimo}

health that must always be maintained and household income which is the impact of the Covid-19 pandemic. This study aims to describe the characteristics of households that buy fruits during the Covid-19 pandemic, what value households are willing to pay for fruits during the Covid-19 pandemic and what factors affect the value of their willingness to pay for fruits. household during the Covid-19 pandemic. This study uses a quantitative design and survey method using a questionnaire. The analysis used is instrument test, descriptive statistical analysis, contingent valuation method, Likert scale and multiple linier regression analysis. The results showed the average value of Willingness To Pay for fruits by households in RW 10, Kel. Cimuning, Kec. Mustika Jaya, Bekasi City varies greatly with each type of fruit. The fruit with the highest average WTP value was green grapes with a value of $R p .83,000 / \mathrm{kg}$ and the fruit with the lowest average WTP value was papaya with a value of Rp. 17,000/kg. The factors that influence the household's willingness to pay for fruits during the Covid-19 pandemic are the health impact, the number of family members and the price of the product.

Keywords: Willingness To Pay, CVM, Fruits, Mustika Jaya District, Covid-19

\section{PENDAHULUAN}

Indonesia terkonfirmasi adanya wabah Covid-19 pada awal Maret 2020. Covid-19 merupakan satu wabah yang berasal dari Wuhan, China dan menyebar ke berbagai negara di dunia. Penyebaran Covid-19 di Indonesia terjadi begitu cepat dan perkembangan kasus positif di Indonesia meningkat dari hari ke hari (Syafrida dan Hartati, 2020).

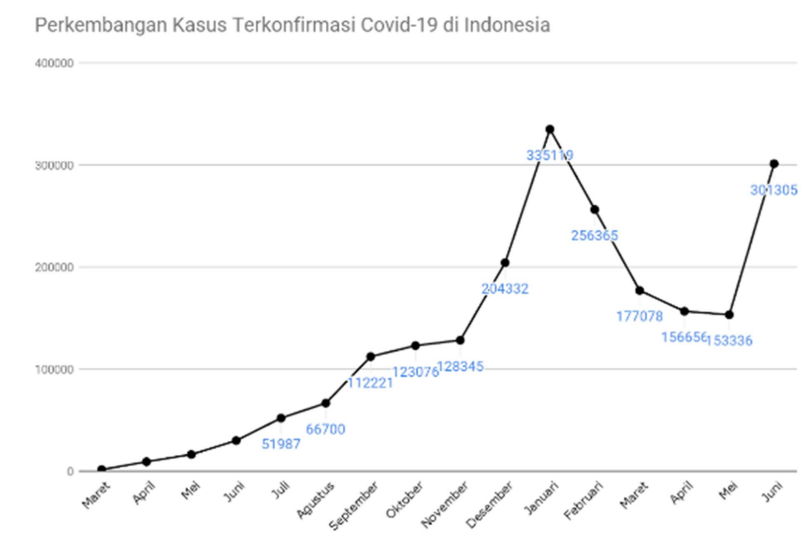

Gambar 1. Kasus Terkonfirmasi Covid-19 di Indonesia Sumber: Gugus Tugas Percepatan Penanganan Covid-19 (2021)

Gambar 1 menunjukkan bahwa kasus terkonfirmasi Covid-19 di Indonesia terjadi peningkatan pada setiap bulan dimulai dari awal terdeteksi nya kasus di Indonesia sampai bulan Desember 2020. Pada awal 2021, kasus terkonfirmasi Covid-19 di Indonesia mengalami penurunan sampai bulan Mei 2021, namun pada bulan Juni 2021 kembali terjadi peningkatan kasus terkonfirmasi Covid-19 di Indonesia. Pertambahan yang terjadi pada bulan Mei 
2021 menuju bulan Juni 2021 adalah sebesar 147.969 jiwa.

Covid-19 disebabkan oleh Coronavirus 2 (SARS CoV-2), yaitu sindrom pernapasan akut. SARS CoV-2 dapat menyebar melalui percikan pernafasan dari hidung atau mulut, atau dapat juga menjadi aerosol. Penularan virus ini juga dapat terjadi dari pasien bergejala atau tanpa gejala dengan tingkat infeksi berkisar antara 0,5\% sampai dengan 5\% (Clerkin, K.J., et al, 2020).

Salah satu cara yang dapat dilakukan untuk mencegah tertularnya penyakit yang disebabkan oleh virus adalah dengan meningkatkan sistem imun atau daya tahan tubuh. Cara yang dapat dilakukan untuk meningkatkan sistem imunitas tubuh adalah menerapkan pola hidup sehat, salah satunya dengan mengkonsumsi sayuran dan buah-buahan di kehidupan sehari-hari. Untuk menjaga agar imun tubuh tetap kuat, maka perlu dijaga dengan memperhatikan jenis makanan yang dapat meningkatkan daya tahan tubuh, mengonsumsi makanan yang mengandung vitamin, seperti vitamin $\mathrm{C}$ dan vitamin A yang mengandung antioksidan untuk menangkal radikal bebas dan meningkatkan kekebalan tubuh (Amalia dan Hiola, 2020). Menurut Khaira (2010), antioksidan bisa dengan mudah didapatkan dari makanan karena berbagai antioksidan telah terdapat secara alamiah terutama dalam sayur-sayuran, buah-buahan dan rempah.

Menurut Kementerian Kesehatan Republik Indonesia (2020), asupan sayur dan buah harus tercukupi untuk mencegah tertular Covid-19. Kecukupan gizi terutama vitamin dan mineral sangat diperlukan dalam mempertahankan sistem kekebalan tubuh yang optimal, buah-buahan dan sayuran merupakan sumber terbaik bebagai vitamin, mineral dan serat. Terdapat beberapa buahbuahan yang direkomendasikan oleh Kementerian Kesehatan Republik Indonesia untuk memenuhi asupan gizi selama pandemi Covid-19 yang dikelompokkan berdasarkan warnanya seperti yang ada pada Tabel 1 .

Tabel 1. Jenis Buah Berdasarkan Warna

\begin{tabular}{cll}
\hline No. & \multicolumn{1}{c}{ Buah-Buahan Berdasarkan Warna } & \multicolumn{1}{c}{ Jenis Buah } \\
\hline 1. & Buah berwarna merah & Semangka, Apel, Stroberi, Anggur merah \\
2. & Buah berwarna kuning dan oranye & Pisang, Jeruk, Pepaya, Mangga, Nanas \\
3. & Buah berwarna hijau & Apel Malang, Anggur Hijau, Melon \\
4. & Buah berwarna ungu dan biru & Manggis \\
\hline
\end{tabular}

Sumber: Kementerian Kesehatan Indonesia (2020) 


\section{ANALISIS KESEDIAAN MEMBAYAR (WILLINGNESS TO PAY) BUAH-BUAHAN \\ PADA RUMAH TANGGA DI KELURAHAN CIMUNING, KECAMATAN MUSTIKA JAYA, KOTA BEKASI SAAT PANDEMI COVID-19 \\ Dhifa Prilia Purnomo, Trisna Insan Noor, Eliana Wulandari, Lucyana Trimo}

Tabel 1 menunjukkan bahwa terdapat buah-buahan berdasarkan warna yang memiliki kandungan berbagai vitamin dan antioksidan yang bermanfaat untuk meningkatkan imunitas tubuh yang direkomendasikan oleh Kementerian Kesehatan Republik Indonesia untuk Masyarakat Indonesia untuk memenuhi asupan gizi selama pandemi Covid-19.

Indonesia dalam menanggapi kasus Covid-19, mengambil kebijakan untuk melakukan pembatasan (karantina wilayah), pelaksanaan kedinasaan work from home (WFH) bagi Aparatur Sipil Negara (ASN) yang secara tegas diatur melalui SE MENPAN-RB No. 34 tahun 2020 tentang Penyesuaian Sistem Kerja ASN dalam Upaya Pencegahan Penyebaran Covid-19 di Lingkungan Instansi Pemerintah. Selain itu, seiring dengan peningkatan kasus positif di Indonesia, pemerintah menerapkan Pembatasan Sosial Berskala Besar (PSBB) dalam Rangka Percepatan Penanganan Covid-19 melalui PP Nomor 21 tahun 2020 (Rohmani, 2020). Menurut survei yang dilakukan Badan Pusat Statistik (2020), dampak mewabahnya Covid-19 semakin dirasakan oleh semua sektor usaha. Sebanyak 41,91\% responden laki-laki dan perempuan mengalami penurunan pendapatan karena terdampak adanya pandemi Covid-19. Penurunan pendapatan sangat dirasakan oleh responden yang sementara dirumahkan akibat terdampak Covid-19 sebanyak 60,74\% responden. Sementara $35,78 \%$ responden yang masih bekerja mengalami penurunan pendapatan.

Kota Bekasi merupakan Kota dengan kasus Covid-19 tertinggi kedua di Jawa Barat yaitu dengan 48.305 kasus yang sudah terkonfirmasi dibandingkan dengan kota atau kabupaten lainnya yang ada di Jawa Barat (Pusat Informasi dan Koordinasi Covid-19 Provinsi Jawa Barat, 2021). Kota Bekasi terdiri atas 12 Kecamatan, yang juga didalamnya terdapat kasus-kasus terkonfirmasi Covid-19 pada setiap kecamatan. Menurut data dari Dinas Kesehatan Kota Bekasi (2021), kecamatan yang paling banyak kasus terkonfirmasi Covid-19 adalah Kecamatan Bekasi Selatan dengan kasus sebanyak 14.789. Sedangkan untuk Kecamatan Mustika Jaya memiliki kasus terkonfirmasi Covid-19 sebanyak 10.583 kasus per bulan Juni 2021. Kecamatan Mustika Jaya terdapat empat kelurahan yang total jumlah penduduknya adalah 277.091 jiwa yang terbagi menjadi 4 kelurahan. Kelurahan dengan kepadatan penduduk tertinggi adalah Kelurahan Cimuning dengan kepadatan 11,40 
jiwa $/ \mathrm{km}^{2}$. Dengan tingkat kepadatan pada Kelurahan Cimuning tersebut, total kasus terkonfirmasi Covid-19 pada Kelurahan Cimuning terhitung pada bulan Juni 2021 adalah sebesar 2.349 kasus (Dinas Kesehatan Kota Bekasi, 2021).

Kelurahan Cimuning, Kecamatan Mustika Jaya merupakan salah satu kelurahan yang penduduknya menerapkan kebijakan pembatasan sosial dan pembatasan fisik. Salah satu daerahnya adalah RW 10. Pada saat Kota Bekasi menerapkan kebijakan PSBB, RW 10 pun membatasi area komplek dengan penjagaan yang ketat pada gerbang masuk dan banyak yang bekerjanya hanya dari rumah. Dengan adanya pandemi covid ini merupakan sebuah tantangan besar untuk seluruh warga agar tetap menjaga kesehatan keluarga agar terhindar dari Covid-19. Berdasarkan informasi dari Satgas Covid-19 RW 10, bahwa telah banyak warga di RW 10 yang terdampak penyakit Covid-19. Keadaan ini membuat masyarakat di RW 10 untuk lebih memperhatikan kesehatan diri masing-masing dan keluarganya karena melihat persebaran dan penularan dari virus ini sangat cepat.

Menurut data BPS (2019), konsumsi buah-buahan masyarakat di Indonesia termasuk di Jawa Barat masih lebih rendah dibandingkan dengan konsumsi sayur-sayuran. Begitu pula dengan rata-rata pengeluaran per kapita sebulan untuk buah-buahan masih lebih kecil dibandingkan dengan sayuran. Pada provinsi Jawa Barat, pengeluaran per kapita sebulan untuk buah-buahan pada penduduk perkotaan yang sebesar $\mathrm{Rp}$ 30.192 juga masih lebih rendah daripada angka pengeluaran per kapita sebulan untuk sayur-sayuran yang sebesar $\mathrm{Rp}$ 40.393 .

Mengetahui hal-hal tersebut menjadi sesuatu yang menarik untuk diteliti mengenai kesediaan membayar buah-buahan, apakah kesediaan membayar buah-buahan masih rendah di masa pandemi Covid-19 seperti yang sedang terjadi. Selain itu, adanya pertimbangan-pertimbangan kesehatan yang harus selalu dijaga agar imunitas tetap kuat yang salah satunya dengan mengonsumsi buah-buahan dan pendapatan yang merupakan dampak yang timbul dari pandemi Covid-19, menjadi hal yang membuat peneliti tertarik untuk meneliti terkait karakteristik rumah tangga yang membeli buah-buahan di RW 10, Kel. Cimuning, Kec. Mustika Jaya, Kota Bekasi selama pandemi Covid-19, Berapa nilai yang sedia dibayarkan oleh rumah tangga di 


\section{ANALISIS KESEDIAAN MEMBAYAR (WILLINGNESS TO PAY) BUAH-BUAHAN \\ PADA RUMAH TANGGA DI KELURAHAN CIMUNING, KECAMATAN MUSTIKA JAYA, KOTA BEKASI SAAT PANDEMI COVID-19 \\ Dhifa Prilia Purnomo, Trisna Insan Noor, Eliana Wulandari, Lucyana Trimo}

RW 10, Kel. Cimuning, Kec. Mustika Jaya, Kota Bekasi untuk buah-buahan selama pandemi Covid-19 dan FaktorFaktor apa saja yang memengaruhi nilai kesediaan membayar atau Willingness To Pay (WTP) buah-buahan pada rumah tangga di RW 10, Kel. Cimuning, Kec. Mustika Jaya, Kota Bekasi selama pandemi Covid-19.

\section{METODE PENELITIAN}

Objek yang dikaji dalam penelitian ini adalah kesediaan membayar buahbuahan pada rumah tangga. Penelitian ini dilakukan di RW 10, Kel. Cimuning, Kec. Mustika Jaya, Kota Bekasi. RW 10 dipilih secara sengaja dengan pertimbangan sudah banyak warga yang terpapar Covid-19 di daerah tersebut yang membuat masyarakat harus lebih memperhatikan kesehatan diri dan keluarga.

Penelitian ini menggunakan desain kuantitatif dengan metode survei. Data yang digunakan pada penelitian ini adalah data primer yang merupakan hasil survei dengan menggunakan kuesioner mengenai kesediaan membayar atau Willingness To Pay buah-buahan pada rumah tangga di RW 10, Kel. Cimuning, Kec. Mustika Jaya, Kota Bekasi selama pandemi Covid-19. Selain itu, penelitian ini juga menggunakan data sekunder yang diperoleh dari jurnal-jurnal tentang penelitian terkait, literatur kepustakaan dan data-data dari sumber-sumber lain yang relevan dengan penelitian ini.

Populasi dalam penelitian ini adalah seluruh rumah tangga yang ada di RW 10, Kelurahan Cimuning, Kecamatan Mustika Jaya, Kota Bekasi. Pada RW 10 terdapat sebelas RT dengan jumlah 276 KK. Pengambilan sampel dalam penelitian ini menggunakan teknik probability sampling, Teknik sampling yang digunakan adalah Proportionate Stratified Random Sampling. Penelitian ini menggunakan rumus slovin untuk menentukan jumlah sampel dengan toleransi kesalahan $(\alpha)$ sebesar $10 \%$ atau 0,1 . Dengan menggunakan rumus slovin dan jumlah populasi 276, maka ukuran sampel adalah 76 responden yang terbagi pada $11 \mathrm{RT}$.

Analisis yang digunakan pada penelitian ini adalah uji instrumen menggunakan uji validitas dan uji reliabilitas, Analisis statistik deskriptif, Contingent Valuation Method (CVM), Skala Likert, analisis regresi linier berganda. Analisis statistik deskriptif digunakan untuk mendeskripsikan karakteristik pada rumah tangga di RW 10, Kel. Cimuning, Kec. Mustika Jaya, 
Kota Bekasi selama pandemi Covid-19. Contingent Valuation Method (CVM) digunakan untuk menghitung nilai kesediaan membayar buah-buahan pada rumah tangga di RW 10, Kel. Cimuning, Kec. Mustika Jaya, Kota Bekasi selama pandemi Covid-19. Menurut Fauzi (2010), dalam prosesnya, terdapat beberapa tahap kegiatan pada metode CVM, yaitu membuat hipotesis pasar, mendapatkan nilai lelang (bids) dan menghitung rataan WTP. Skala Likert digunakan untuk mengukur sifat-sifat individu dengan menggunakan skor total dari butir pertanyaan adalah skala pengukuran interval, sedangkan butirbutir pertanyaan yang menggunakan tipe data likert mempunyai skala pengukuran ordinal (Budiaji, 2013). Skala likert yang digunakan pada penelitian ini menggunakan bobot 1-5, yaitu:

- $1=$ Sangat tidak setuju

- 2 = Tidak setuju

- 3 = Biasa saja

- $4=$ Setuju

- $5=$ Sangat setuju

Analisis regresi linier berganda merupakan model persamaan yang menjelaskan hubungan satu variabel tak bebas atau response (Y) dengan dua atau lebih variabel bebas/predictor $\left(\mathrm{X}_{1}, \mathrm{X}_{2}, \ldots \mathrm{X}_{\mathrm{n}}\right)$ dan juga untuk dapat mengetahui bagaimanakah arah hubungan variabel tak bebas dengan variabel bebasnya (Yuliara, 2016). Pada penelitian ini, analisis ini digunakan untuk menganalisis faktor-faktor yang memengaruhi nilai kesediaan membayar atau Willingness To Pay buah-buahan pada rumah tangga di RW 10 Kel. Cimuning, Kec. Mustika Jaya, Kota Bekasi selama pandemi Covid-19. Adapun model regresi linier berganda dalam penelitian ini adalah:

$$
\begin{gathered}
Y=a+b_{1} X_{1}+b_{2} X_{2}+b_{3} X_{3}+b_{4} X_{4} \\
+b_{5} X_{5}+b_{6} X_{6}
\end{gathered}
$$

Dengan variabel:

$\mathrm{Y}=$ Kesediaan membayar rumah tangga terhadap buah-buahan selama pandemi Covid-19.

$\mathrm{X}_{1}=$ tingkat pendidikan

$\mathrm{X}_{2}=$ pendapatan

$\mathrm{X}_{3}=$ kualitas produk

$\mathrm{X}_{4}=$ dampak kesehatan

$\mathrm{X}_{5}=$ jumlah anggota keluarga

$\mathrm{X}_{6}=$ harga produk 


\section{HASIL DAN PEMBAHASAN}

\section{Karakteristik Rumah Tangga}

1) Tingkat Pendidikan

Tabel 2. Data Tingkat Pendidikan Rumah Tangga

\begin{tabular}{clcc}
\hline No. & Karakteristik Tingkat Pendidikan & Jumlah Rumah Tangga (Orang) & Presentase (\%) \\
\hline 1. & Tidak tamat SD & 0 & 0 \\
2. & SD & 0 & 0 \\
3. & SMP & 0 & 0 \\
4. & SMA & 22 & 30 \\
5. & Perguruan Tinggi & 51 & 70 \\
\hline \multicolumn{2}{r}{ Total } & $\mathbf{7 3}$ & $\mathbf{1 0 0}$ \\
\hline
\end{tabular}

Sumber: Data Primer, 2020 (Diolah)

Berdasarkan hasil penelitian, tingkat pendidikan rumah tangga terbanyak adalah tingkat pendidikan Perguruan Tinggi, yaitu sebesar 70 persen dari total 73 responden. Tingkat pendidikan rumah tangga pun hanya terbagi menjadi dua yaitu tingkat pendidikan SMA dan Perguruan Tinggi

2) Pekerjaan dari lima kriteria tingkat pendidikan yang ada. Hal ini menunjukkan bahwa mayoritas warga di RW 10 merupakan orang-orang yang telah menjalani pendidikan di perguruan tingi dan mengutamakan pendidikan di kehidupannya.

Tabel 3. Data Pekerjaan Rumah Tangga

\begin{tabular}{clcc}
\hline No. & \multicolumn{1}{c}{ Karakteristik Pekerjaan } & Jumlah Rumah Tangga (Orang) & Presentase (\%) \\
\hline 1. & PNS & 1 & 1 \\
2. & Pegawai Swasta & 18 & 25 \\
3. & Wiraswasta & 11 & 15 \\
4. & Ibu Rumah Tangga & 40 & 55 \\
5. & Lainnya & 3 & 4 \\
\hline \multicolumn{2}{r}{ Total } & $\mathbf{7 3}$ & $\mathbf{1 0 0}$ \\
\hline
\end{tabular}

Sumber: Data Primer, 2020 (Diolah)

Tabel 3 menunjukkan hasil penelitian dari pekerjaaan rumah tangga. Pekerjaan rumah tangga terbanyak adalah sebagai ibu rumah tangga dengan presentase sebesar 55\% dari total 73 rumah tangga, yang artinya sebagian besar warga di RW 10 hanya mengurus keperluan rumah tangga. Kemudian untuk 45\% lainnya memiliki pekerjaan yang terbagi menjadi PNS, Pegawai Swasta, Wiraswasta dan lainnya. Pekerjaan yang termasuk pada karakteristik lainnya adalah pegawai 
BUMN, pegawai pemerintah dan

wirausaha.

3) Usia

Tabel 4. Data Usia Rumah Tangga

\begin{tabular}{|c|c|c|c|}
\hline No. & Usia (tahun) & Jumlah Rumah Tangga (Orang) & Presentase (\%) \\
\hline 1. & $15-64$ & 73 & 100 \\
\hline 2. & $\geq 65$ & 0 & 0 \\
\hline & Total & 73 & 100 \\
\hline
\end{tabular}

Tabel 4 menunjukkan bahwa seluruh rumah tangga pada penelitian ini berada pada rentang usia 15-64 tahun. Menurut BPS (2015), usia produktif seseorang berada pada rentang usia 15-64 tahun, usia belum produktif pada rentang usia 0-14 tahun dan usia tidak produktif berada pada usia 65 tahun keatas. Hasil

4) Jumlah Tanggungan Keluarga penelitian menunjukkan bahwa rumah tangga di RW 10 berada pada rentang usia produktif. Berdasarkan hasil penelitian, rata-rata usia dari rumah tangga yang bersedia membayar buahbuahan saat pandemi Covid-19 pada penelitian ini adalah 45 tahun.

Tabel 5. Data Jumlah Tanggungan Keluarga Rumah Tangga

\begin{tabular}{cccc}
\hline No & Jumlah Tanggungan Keluarga & Jumlah Rumah Tangga (Orang) & Presentase (\%) \\
\hline 1. & 1 & 6 & 8 \\
2. & 2 & 20 & 27 \\
3. & 3 & 8 & 11 \\
4. & 4 & 21 & 29 \\
5. & 5 & 15 & 21 \\
6. & 6 & 3 & 4 \\
\hline
\end{tabular}

Sumber: Data Primer, 2020 (Diolah)

Tabel 5 menunjukkan jumlah tanggungan keluarga dari rumah tangga di RW 10. Jumlah tanggungan keluarga terbanyak pada rumah tangga di RW 10 adalah tanggungan keluarga berjumlah 4 orang dengan presentase $29 \%$ dari total
73 responden. Jumlah tanggungan keluarga paling sedikit dari rumah tangga di RW 10 adalah tanggungan keluarga berjumlah 6 orang dengan presentase 4\% dari total 74 responden. 
ANALISIS KESEDIAAN MEMBAYAR (WILLINGNESS TO PAY) BUAH-BUAHAN

PADA RUMAH TANGGA DI KELURAHAN CIMUNING, KECAMATAN MUSTIKA JAYA,

KOTA BEKASI SAAT PANDEMI COVID-19

Dhifa Prilia Purnomo, Trisna Insan Noor, Eliana Wulandari, Lucyana Trimo

5) Pendapatan Rumah Tangga

Tabel 6. Data Pendapatan Rumah Tangga

\begin{tabular}{|c|c|c|c|}
\hline No. & Karakteristik Pendapatan & Jumlah Rumah Tangga (Orang) & Presentase $(\%)$ \\
\hline 1. & $\mathrm{Rp} \leq 2.500 .000$ & 4 & 6 \\
\hline 2. & Rp 2.500 .000 - Rp 5.000.000 & 14 & 19 \\
\hline 3. & Rp 5.000.000 - Rp 7.500.000 & 21 & 29 \\
\hline 4. & Rp 7.500.000 - Rp 10.000.000 & 17 & 23 \\
\hline 5. & $\mathrm{Rp}>10.000 .000$ & 17 & 23 \\
\hline & Total & 73 & 100 \\
\hline
\end{tabular}

Sumber: Data Primer, 2020 (Diolah)

Tabel 6 menunjukkan bahwa mayoritas pendapatan rumah tangga di RW 10 berada pada rentang $\mathrm{Rp}$ 5.000 .000 - Rp 7.500.000 dengan presentase sebesar $29 \%$ dari total 73 rumah tangga. Jumlah rumah tangga paling sedikit berada pada rentang pendapatan $\mathrm{Rp} \leq 2.500 .000$ dengan presentase $6 \%$ dari total 73 responden.

\section{Nilai Kesediaan Membayar}

\section{(Willingness To Pay) Buah-Buahan}

Nilai Kesediaan Membayar (Willingness To Pay) buah-buahan pada RW 10, Kel. Cimuning, Kec. Mustika Jaya, Kota Bekasi saat Pandemi Covid-19 ini didapatkan oleh peneliti melalui tahap pencarian informasi kepada rumah tangga dengan cara memberikan kuesioner dimana pada keadaan saat ini peneliti melakukan secara online mengingat kondisi penduduk di RW 10 terdapat beberapa yang terpapar Covid-19. Buahbuahan yang dianalisis kesediaan membayarnya pada penelitian ini adalah buah-buahan yang direkomendasikan oleh Kementerian Kesehatan Republik Indonesia untuk memenuhi asupan gizi selama pandemi Covid-19 yaitu semangka, apel, stroberi, anggur merah, pisang, jeruk, pepaya, mangga, nanas, apel malang, anggur hijau, melon dan manggis. Namun, hasil penelitian yang dilakukan menunjukkan ada beberapa buah dari yang sudah direkomendasikan oleh Kementerian Kesehatan RI yang tidak dikonsumsi oleh rumah tangga, yaitu apel malang dan manggis. Terdapat juga beberapa buah-buahan yang tidak dalam daftar rekomendasi Kementerian Kesehatan RI namun dikonsumsi oleh rumah tangga, yaitu alpukat, jambu merah, kiwi dan pir.

Menurut Fauzi (2010), menentukan nilai kesediaan membayar dapat menggunakan metode CVM (Contingent Valuation Method) yang dilakukan dengan beberapa tahapan. 
1) Nilai Hipotesis Pasar

Berdasarkan hasil survei kepada rumah tangga mengenai nilai kesediaan membayar buah-buahan selama pandemi Covid-19, nilai yang bersedia dibayarkan sangat variatif sesuai dengan jenis buah yang dikonsumsi. Dari 73 rumah tangga, sebanyak $5.4 \%$ rumah tangga bersedia membayarkan jenis buah-buahan tertentu yang dikonsumsinya dengan harga yang sama dengan harga beli buah tersebut. Sementara itu hanya $0.4 \%$ rumah tangga yang bersedia membayar harga beberapa buah tertentu dari yang dikonsumsinya kurang dari harga beli buah tersebut, sedangkan untuk 94.2\% lainnya bersedia membayar buah-buahan yang dikonsumsinya lebih besar dari harga beli dari buah-buahan tersebut.

Menurut beberapa rumah tangga yang bersedia membayar buah-buahan dengan harga lebih besar dari harga beli buah-buahan tersebut, alasan bersedia membayar lebih adalah karena sudah mengetahui beberapa manfaat dari buahbuahan yang dikonsumsi terutama saat pandemi Covid-19 dimana perlu lebih banyak asupan vitamin untuk menjaga imunitas tubuh dan buah-buahan menjadi makanan yang wajib ada untuk dikonsumsi setiap hari oleh anggota keluarga. Selain itu, berdasarkan hasil penelitian, frekuensi pembelian buahbuahan juga dapat berpengaruh terhadap kesediaan membayar buah-buahan pada rumah tangga di RW 10.

2) Nilai Lelang

Tahapan ini dilakukan untuk memperoleh nilai yang sebenarnya bersedia dibayarkan oleh setiap rumah tangga terhadap buah-buahan selama pandemi Covid-19. Teknik yang dilakukan pada tahap ini adalah menggunakan teknik open ended question (pertanyaan terbuka). Pertanyaan terbuka yang diberikan kepada setiap rumah tangga adalah pertanyaan mengenai berapa nilai maksimum yang akan dibayarkan terhadap buah-buahan selama pandemi Covid-19 tanpa ada batasan nilai penawaran yang diberikan kepada setiap rumah tangga. Nilai yang bersedia dibayarkan oleh setiap rumah tangga di RW 10 adalah didasarkan dengan harga beli buah-buahan pada masing-masing rumah tangga. Nilai WTP pada setiap buah-buahan yang dikonsumsi rumah tangga sangat bervariasi.

3) Nilai Rataan WTP

Setelah survei dilakukan dan mendapatkan nilai lelang dari masingmasing buah yang dikonsumsi, tahapan selanjutnya adalah menghitung nilai 


\section{ANALISIS KESEDIAAN MEMBAYAR (WILLINGNESS TO PAY) BUAH-BUAHAN \\ PADA RUMAH TANGGA DI KELURAHAN CIMUNING, KECAMATAN MUSTIKA JAYA, \\ KOTA BEKASI SAAT PANDEMI COVID-19 \\ Dhifa Prilia Purnomo, Trisna Insan Noor, Eliana Wulandari, Lucyana Trimo}

rataan kesediaan membayar (WTP). Nilai rataan WTP ini didapatkan dari nilai lelang yang sudah didapatkan dari tiap rumah tangga terhadap buah-buahan yang dikonsumsinya. Nilai rataan WTP didapatkan dari jumlah total nilai kesediaan membayar dari rumah tangga pada masing-masing buah dibagi dengan jumlah rumah tangga yang bersedia membayar buah tersebut.

Tabel 7. Nilai Rataan Willingness To Pay dan Rata-Rata Harga Beli Buah-Buahan yang Dikonsumsi Oleh Rumah Tangga di RW 10, Kelurahan Cimunung, Kecamatan Mustika Jaya, Kota Bekasi

\begin{tabular}{|c|c|c|c|}
\hline No. & Buah & Nilai Rataan WTP & Rata-Rata Harga Beli Buah \\
\hline 1. & Semangka & $\mathrm{Rp} 22.000 / \mathrm{kg}$ & $\mathrm{Rp} 17.000 / \mathrm{kg}$ \\
\hline 2. & Apel & $\mathrm{Rp} 39.000 / \mathrm{kg}$ & $\operatorname{Rp} 31.000 / \mathrm{kg}$ \\
\hline 3. & Stroberi & $\operatorname{Rp} 24.000 / 250 \mathrm{gr}$ & $\operatorname{Rp} 17.000 / 250 \mathrm{gr}$ \\
\hline 4. & Anggur Merah & $\mathrm{Rp} 61.000 / \mathrm{kg}$ & $\mathrm{Rp} 52.000 / \mathrm{kg}$ \\
\hline 5. & Pisang & $\operatorname{Rp} 20.000 / \mathrm{kg}$ & $\operatorname{Rp} 15.000 / \mathrm{kg}$ \\
\hline 6. & Jeruk & $\mathrm{Rp} 33.000 / \mathrm{kg}$ & $\operatorname{Rp} 26.000 / \mathrm{kg}$ \\
\hline 7. & Pepaya & $\mathrm{Rp} 17.000 / \mathrm{kg}$ & $\operatorname{Rp} 12.000 / \mathrm{kg}$ \\
\hline 8. & Mangga & $\mathrm{Rp} 22.000 / \mathrm{kg}$ & $\operatorname{Rp} 16.000 / \mathrm{kg}$ \\
\hline 9. & Nanas & $\mathrm{Rp} 23.000 / \mathrm{kg}$ & $\operatorname{Rp} 15.000 / \mathrm{kg}$ \\
\hline 10. & Anggur Hijau & $\mathrm{Rp} 83.000 / \mathrm{kg}$ & $\mathrm{Rp} 76.000 / \mathrm{kg}$ \\
\hline 11. & Melon & $\mathrm{Rp} 23.000 / \mathrm{kg}$ & $\operatorname{Rp} 17.500 / \mathrm{kg}$ \\
\hline 12. & Alpukat & $\mathrm{Rp} 38.000 / \mathrm{kg}$ & $\operatorname{Rp} 31.000 / \mathrm{kg}$ \\
\hline 13. & Jambu Merah & $\mathrm{Rp} 30.000 / \mathrm{kg}$ & $\mathrm{Rp} 29.000 / \mathrm{kg}$ \\
\hline 14. & Kiwi & $\mathrm{Rp} 47.500 / \mathrm{kg}$ & $\operatorname{Rp} 37.500 / \mathrm{kg}$ \\
\hline 15. & Pir & $\mathrm{Rp} 40.000 / \mathrm{kg}$ & $\operatorname{Rp} 30.000 / \mathrm{kg}$ \\
\hline
\end{tabular}

Sumber: Data Primer, 2020 (diolah)

Tabel 7 menunjukkan hasil nilai rataan WTP dan Rata-Rata Harga Beli terhadap 15 jenis buah-buahan yang dikonsumsi oleh rumah tangga di RW 10 selama pandemi Covid-19. Buah dengan nilai rataan WTP tertinggi berada pada buah anggur hijau dengan nilai $\mathrm{Rp}$ $83.000 / \mathrm{kg}$. Buah dengan nilai rataan WTP terendah yaitu buah pepaya dengan nilai $\mathrm{Rp} 17.000 / \mathrm{kg}$. Buah anggur hijau memiliki nilai rataan WTP tertinggi disebabkan oleh tingginya harga beli dari anggur hijau tersebut sehingga rumah tangga yang mengonsumsi bersedia membayar untuk buah anggur hijau lebih besar dari harga belinya. Buah pepaya menjadi buah dengan nilai rataan WTP terendah karena harga beli dari buah pepaya yang rendah per kg nya, sehingga nilai kesediaan membayarnya pun masih lebih rendah daripada buah-buah lainnya. Buah jambu merah memiliki selisih nilai terkecil karena yang mengonsumsinya hanya 1 rumah tangga sehingga rata-rata dari harga belinya pun haya dari 1 rumah tangga yang bersedia membayar Rp 1.000 lebih besar dari harga beli buah jambu merah tersebut. Buah kiwi dan pir memiliki selisih nilai yang sama yaitu $\mathrm{Rp}$ 10.000 dan nilai tersebut merupakan 
selisih tertinggi, hal ini dapat terjadi karena jumlah yang mengonsumsi buah tersebut hanya sedikit yaitu buah kiwi 2 rumah tangga dan pir 1 rumah tangga. Dengan begitu nilai rataan WTP nya sesuai dengan kesediaan membayar tiap rumah tangga terhadap buah kiwi dan pir tersebut.

\section{Faktor-Faktor yang Memengaruhi}

\section{Kesediaan Membayar Buah-buahan}

Hasil dari nilai kesediaan membayar pada masing-masing rumah tangga terhadap buah-buahan yang dikonsumsi kemudian dianalisis untuk mengetahui sejauh mana pengaruhpengaruh dari setiap variabel faktor yang memengaruhi terhadap nilai kesediaan membayar yang telah ditentukan. Pada penelitian ini, variabel yang digunakan adalah tingkat pendidikan, pendapatan keluarga, kualitas produk, dampak kesehatan, jumlah anggota keluarga dan harga produk. Faktor-faktor yang memengaruhi kesediaan membayar buahbuahan ini dianalisis menggunakan regresi linier berganda dengan menggunakan SPSS. Kemudian setelahnya dilakukan uji hipotesis untuk mengetahui apakah variabel-variabel faktor yang memengaruhi tersebut berpengaruh secara parsial dan simultan terhadap kesediaan membayar buahbuahan pada rumah tangga di RW 10 selama pandemi Covid-19.

Tabel 8. Hasil Uji Parsial

\begin{tabular}{|c|c|c|c|c|c|}
\hline & Model & $\mathbf{T}_{\text {hitung }}$ & $\mathbf{T}_{\text {tabel }}$ & Nilai Signifikansi & Keterangan \\
\hline 1 & (Constant) & 0.908 & & 0.367 & \\
\hline & Tingkat Pendidikan $\left(\mathrm{X}_{1}\right)$ & 0.717 & 1.993 & 0.476 & Tidak Signifikam \\
\hline & Pendapatan $\left(\mathrm{X}_{2}\right)$ & -0.001 & 1.993 & 0.999 & Tidak Signifikam \\
\hline & Kualitas Produk $\left(\mathrm{X}_{3}\right)$ & 0.975 & 1.993 & 0.333 & Tidak Signifikam \\
\hline & Dampak Kesehatan $\left(\mathrm{X}_{4}\right)$ & 2.322 & 1.993 & 0.023 & Signifikan \\
\hline & Jumlah Anggota Keluarga $\left(\mathrm{X}_{5}\right)$ & 2.094 & 1.993 & 0.04 & Signifikan \\
\hline & Harga Produk $\left(\mathrm{X}_{6}\right)$ & 2.546 & 1.993 & 0.013 & Signifikan \\
\hline
\end{tabular}

Sumber: Data Primer, 2020 (diolah)

Berdasarkan hasil yang ditunjukkan pada Tabel 8, variabel yang dapat memengaruhi kesediaan membayar buahbuahan pada rumah tangga saat pandemi Covid-19 adalah dampak kesehatan, jumlah anggota keluarga dan harga produk. Dampak Kesehatan memiliki nilai pengaruh yang positif, hal ini berarti apabila semakin besar dampak kesehatan yang diberikan dari buah-buahan tersebut maka semakin besar juga nilai kesediaan membayar buah-buahan selama pandemi Covid-19 pada rumah tangga. Hal ini menunjukkan bahwa rumah tangga sudah menyadari bahwa mengonsumsi buahbuahan selama pandemi Covid-19 


\section{ANALISIS KESEDIAAN MEMBAYAR (WILLINGNESS TO PAY) BUAH-BUAHAN \\ PADA RUMAH TANGGA DI KELURAHAN CIMUNING, KECAMATAN MUSTIKA JAYA, KOTA BEKASI SAAT PANDEMI COVID-19 \\ Dhifa Prilia Purnomo, Trisna Insan Noor, Eliana Wulandari, Lucyana Trimo}

sangatlah penting untuk kesehatan keluarga. Hasil penelitian ini sesuai dengan pernyataan Rofiatin dan Bariska (2018), yaitu dampak kesehatan memiliki pengaruh positif karena masyarakat menyadari betapa pentingnya pola hidup sehat yang sangat berpengaruh pada pola konsumsi yang mereka makan.

Jumlah anggota keluarga memiliki nilai pengaruh yang positif yang memiliki arti pada saat jumlah anggota keluarga pada rumah tangga di RW 10 bertambah maka jumlah uang yang bersedia dibayarkan oleh rumah tangga tersebut untuk buah-buahan selama pandemi Covid-19 semakin tinggi. Pada penelitian ini, mayoritas rumah tangga memiliki jumlah anggota keluarga sebanyak empat orang atau lebih. Sehingga semakin banyak anggota keluarga maka kesediaan membayar terhadap buah-buahan selama pandemi Covid-19 semakin tinggi. Namun, tidak menutup kemungkinan untuk rumah tangga yang jumlah anggota keluarganya sedikit memiliki nilai kesediaan membayar yang lebih tinggi. Karena hal tersebut tergantung kepada daya beli dan preferensi masing-masing rumah tangga terhadap konsumsi buahbuahan selama pandemi Covid-19. Hasil penelitian yang dilakukan oleh Yunus, Siswadi dan Syakir (2019), menyatakan bahwa variabel jumlah anggota keluarga memiliki pengaruh yang negatif, yaitu apabila konsumen dengan jumlah anggota keluarga lebih banyak akan mengambil keputusan untuk tidak bersedia membayar lebih banyak. Hal tersebut berbeda dengan penelitian yang dilakukan saat ini, karena saat ini sedang berada dalam keadaan pandemi Covid19, dimana mengonsumsi buah-buahan menjadi hal yang penting untuk meningkatkan imunitas tubuh terlebih apabila terdapat anggota keluarga yang harus tetap melakukan aktivitas diluar rumah.

Harga produk memiliki nilai pengaruh positif terhadap kesediaan membayar buah-buahan selama pandemi Covid-19 yang berarti apabila harga produk buah-buahan naik maka nilai kesediaan membayar buah-buahan pada rumah tangga selama pandemi Covid-19 juga akan meningkat. Pada penelitian yang dilakukan oleh Rofiatin dan Bariska (2018), menyatakan bahwa variabel harga produk memiliki pengaruh negatif terhadap kesediaan membayar, hal ini berarti pada saat harga produk naik maka kesediaan membayar turun, namun tetap akan membeli produk tersebut dengan kuantitas yang dikurangi. Hasil penelitian tersebut berbeda dengan penelitian yang 
dilakukan saat ini, karena pada saat ini terdapat suatu kondisi yang berbeda yaitu Covid-19, yang mengharuskan seseorang untuk lebih memperhatikan kesehatan untuk diri sendiri dan keluarga.

\section{KESIMPULAN DAN SARAN}

\section{Kesimpulan}

1) Karakteristik rumah tangga yang membeli buah-buahan di RW 10, Kelurahan Cimuning, Kecamatan Mustika Jaya, Kota Bekasi mayoritas adalah ibu rumah tangga dengan tingkat pendidikan perguruan tinggi, berada pada usia 15-64 tahun dengan jumlah tanggungan keluarga 4 orang dan pendapatan rumah tangga $\mathrm{Rp}$ $5.000 .000-\operatorname{Rp} 7.500 .000$.

2) Nilai rataan kesediaan membayar (Willingness To Pay) terhadap buahbuahan oleh rumah tangga di RW 10, Kel. Cimuning, Kec. Mustika Jaya, Kota Bekasi sangat bervariasi berbeda setiap jenis buahnya. Buah dengan nilai rataan WTP tertinggi adalah buah anggur hijau dengan nilai $\mathrm{Rp}$ $83.000 / \mathrm{kg}$ dan buah dengan nilai rataan WTP terendah adalah buah pepaya dengan nilai $\mathrm{Rp} 17.000 / \mathrm{kg}$.

3) Faktor-faktor yang memengaruhi terhadap kesediaan membayar buahbuahan pada rumah tangga di RW 10
Kel. Cimuning, Kec. Mustika Jaya, Kota Bekasi adalah variabel dampak kesehatan, jumlah anggota keluarga dan harga produk yang berpengaruh signifikan secara parsial terhadap kesediaan membayar buah-buahan selama pandemi Covid-19. Variabel yang tidak signifikan berpengaruh terhadap kesediaan membayar buahbuahan selama pandemi Covid-19 adalah tingkat pendidikan, pendapatan dan kualitas produk. Sementara itu seluruh variabel independen yaitu tingkat pendidikan, pendapatan, kualitas produk, dampak kesehatan, jumlah anggota keluarga dan harga produk berpengaruh signifikan secara simultan terhadap kesediaan membayar buah-buahan selaama pandemi Covid-19.

\section{Saran}

1) Bagi pemerintah atau pemegang kebijakan, disarankan untuk selalu memberikan arahan-arahan dan pemberitahuan kepada masyarakat Indonesia mengenai panduan buahbuahan yang baik untuk dikonsumsi selama pandemi Covid-19 untuk meningkatkan imunitas tubuh.

2) Bagi peneliti lain, berdasarkan hasil penelitian ini agar bisa dijadikan 
sebagai referensi atau acuan dalam melakukan penelitian lain yang berkaitan dengan penelitian yang sudah dilakukan. Diharapkan juga dapat mengembangkan penelitian ini menjadi penelitian yang lebih spesifik dan mendetail dengan tambahan beberapa variabel-variabel lain yang akan memengaruhi kesediaan membayar buah-buahan seperti variabel pekerjaan dan usia responden.

\section{UCAPAN TERIMA KASIH}

Ucapan terima kasih disampaikan kepada semua pihak yang telah berperan dalam penelitian hingga penulisan artikel ini dengan baik dan lancar.

\section{DAFTAR PUSTAKA}

Amalia, L. dan Hiola, F. 2020. "Analisis Gejala Klinis Dan Peningkatan Kekebalan Tubuh Untuk Mencegah Penyakit Covid-19." Jambura Journal of Health Sciences and Research, 2(2), 71-76.

Badan Pusat Statistik. 2019. Statistik Pendapatan Februari 2019. Jakarta: BPS-RI.

Badan Pusat Statistik. 2020. Hasil Survei Sosial Demografi Dampak Covid19.

Budiaji, W. 2013. "Skala Pengukuran Dan Jumlah Respon Skala Likert". Jurnal ilmu pertanian dan perikanan, 2(2), 127-133.
Clerkin, K. J., Fried, J. A., Raikhelkar, J., Sayer, G., Griffin, J. M., Masoumi, A., ... dan Schwartz, A. 2020. "COVID-19 and Cardiovascular Disease." Circulation, 141(20), 1648-1655.

Fauzi, A. 2010. Ekonomi Sumber Daya Alam dan Lingkungan. Jakarta: Gramedia.

Gugus Tugas Percepatan Penanganan Covid-19. 2020. Peta Sebaran Covid-19. Retrieved From https://covid19.go.id/peta-sebaran

Kementerian Kesehatan Republik Indonesia. 2020. Panduan Gizi Seimbang Pada Masa Pandemi Covid-19

Khaira, K. 2010. "Menangkal Radikal Bebas dengan Anti-oksidan." Sainstek: Jurnal Sains dan Teknologi, 2(2), 183-187.

Rofiatin, U. dan Bariska, H. F. 2018. "Pola Willingness To Pay (WTP) Dan Faktor-Faktor Yang Memengaruhi Terhadap Pilihan Sayur Organik Dan Anorganik Masyarakat Kota Malang." OPTIMA, 2(1), 18-26.

Syafrida dan Hartati, R. 2020. "Bersama Melawan Virus Covid 19 di Indonesia." Jurnal Sosial dan Budaya Syar-i. 7(6). 495-508.

Yuliara, I. 2016. Modul Regresi Linier Berganda.

Yunus, I. W., Siswadi, B. dan Syakir, F. 2019. "Analisis Kesediaan Membayar (Willingness To Pay) Sayuran Organik Dan Faktor Yang Memengaruhi Di Kota Malang." Jurnal Sosial Ekonomi Pertanian dan Agribisnis, 7(4). 